\title{
The Distribution of Life in the Southern Hemisphere, and its Bearing on Wegener's Hypothesis.
}

NE of the most important results of the acceptance of Wegener's theory of the palæogeography of the world would be the simplification of the facts of the Permo-Carboniferous glaciation of Australia, India, South Africa, and South America by bringing the glaciated areas together into one single glaciated region. It is undoubted that if this were done much of the difficulty of accounting for the simultaneous glaciation of regions so diverse in latitude would disappear. Considerable interest, therefore, attaches to the recent discussion on Wegener's hypothesis, which was held before the Royal Society of South Africa, for its bearing on this important aspect of the subject.

The general attitude of the geologists who took part in the discussion was one of suspended judgment. It is admitted that the folded ranges of the Sierras of Buenos Aires appear to be of similar age and structure to those of the southern folded belt of the Cape Province, and would be brought into fairly accurate aligniment if the South American coast were fitted into the African coast after the manner of Wegener's map of Carboniferous land distribution, but it was held that this might be accounted for in several other ways more in accord with the known facts of geology. On the other hand, the very close and detailed homology of the Tertiary deposits of Grahamland and Patagonia as described by Gunnar Andersson forms one of the most relevant pieces of combined geological and palæontological evidence from the southern hemisphere in support of the theory.

Discussing the zoological evidence, Mr. K. H. Barnard concludes that the zoologist, far from being able to help in formulating an explanation of the palæogeographical history of the continents, was, in reality, entirely dependent on the geophysicist and geologist, and that in some cases the facts of presentday distribution were capable of interpretation in terms either of a far-reaching equatorial Gondwanaland or a compact polar Gondwanaland. There is little to choose, for example, between Watson's theory of the dispersal of acarid snails from S.E. Asia [equatorial Gondwanaland] and Hedley's theory of their origin in Antarctica [polar Gondwanaland], and whichever geological theory best explains the palæogeographical changes must be used as a basis by zoologists. Similarly, if the ancestors of the freshwater crayfishes originated in an arm of the IndoPacific which gradually penetrated into polar Gondwanaland in pre-Jurassic times, the same results will follow as those sketched out by Ortmann for post-Jurassic times. The distribution of Peripatus, on the other hand, is apparently best explained on the polar Gondwanaland hypothesis. If the distribution of the species of Peripatus is plotted on a polar projection map, it is remarkable that the Peripatopsidæ, the more specialised group, occupy a central position, while the Peripatidæ, the more primitive, are peripheral. The most important zoological evidence in support of Wegener's theory is provided by the isopod, Phreatoicus. At the present time it is found in Australia, Tasmania, New Zealand, and South Africa. There is the closest possible likeness between some of the Australian species and the Cape form. In Australia there is also a fossil species of Triassic age, which provides almost positive proof that the animal was not only palæogenic, but also austrogenic, and that the regions where it exists to-day were once in the very closest relationship to one another.

Dr. Peringuey, discussing the entomological evidence, concludes that the present distribution of insects is as readily accounted for by the geological theories now obtaining as by Wegener's hypothesis, and believes that the latter will receive little if any support from entomology. He agrees that the key will be found in palæo-entomology, but is forced to admit that the evidence from fossil insects is at present too inadequate to be of value. Discussing the special case of the Coleopteron genus Carabus, first found in Jurassic times, Dr. Peringuey points out that it is unknown in the Old World south of the Sahara, but one species occurs in St. Helena and seven in Chile. He regards the St. Helena and Chilian forms as survivals from an equatorial Gondwanaland, in isolated spots at high altitudes, and not as evidence of the former connexion of South America and St. Helena, in their present form, with South Africa, where the genus is absent, or with Australia, where the genus is unknown but where its vitality should have ensured its success. On the other hand, the nearest ally of Carabus, the genus Calosoma, has three species in South Africa, three in Australia, one in the Galapagos Islands, and one in Patagonia, a distribution which seems to support the unity of the continents alleged by Wegener. In Australia there is a group of large Curculionidæ, one of the families of Coleoptera, which so much resembles a purely South African group of the same family that, at first sight, the two might be taken to represent the same stock in two now widely separated continents. Dr. Peringuey, however, regards this as a case of convergence.

Prof. Compton regards the botanical evidence as completely opposed to Wegener's theory. The perfection of the means of dispersal of plants renders many of the facts as to the modern distribution of ancient groups (Cryptogams) almost valueless as an indication of former land connexions. Recent phyla only, especially the Angiosperms, can be relied on. The Angiosperms arose during Cretaceous times, and most modern families are represented in the Eocene. The Wegener hypothesis contemplates a wide disruption of South Africa and Australia in the Jurassic epoch, but South Africa and South America were only separated by a very narrow strait at the end of the Cretaceous period. Yet the floristic resemblances between temperate South Africa and South America are much less conspicuous than between temperate South Africa and Australia. The floristic relationships between South Africa, South America, and Australia are best explained as being due to lateral migration, perhaps in the warmer Miocene, from a comprehensive tropical belt of vegetation, containing most of the great Angiosperm families, which stretched round the world except the Pacific. The south temperate floras, therefore, are linked through the tropics except for South America and New Zealand, which certainly seem to have been connected by land, via Antarctica, in the Miocene. The modern distribution of the Rutaceæ is an excellent instance of the progress of migration southwards as well as northwards from this tropical belt, and tentative explanations of the distribution of the Proteaceæ and Restionaceæ may be given on the same lines. Dr. Du Toit regards the palæobotanical evidence as too fragmentary for botanists to do more than make guesses at the probable origin of the South African flora.

The net result of this interesting discussion is to emphasise the importance of further work on the palæontology of the southern hemisphere. In that direction alone will be found the key to the correct interpretation of the known facts of the present day distribution of animals and plants, and of the palæogeographical changes which have taken place.

$$
\text { NO. } 2778 \text {, voL. I I I] }
$$

